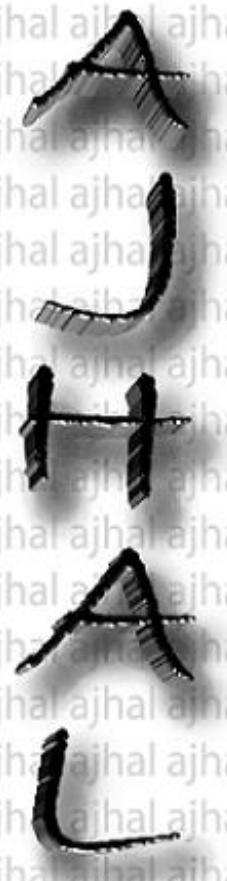

[SSN 2311-8636

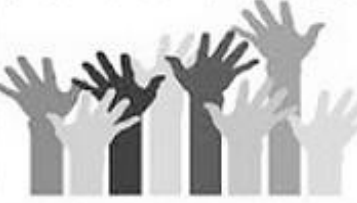

THHERET5חQ 토月P工田

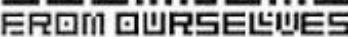
тा브 HயாПП 코느ㅌㅣㅐ.

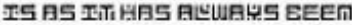
月กㅋ 트 미니트

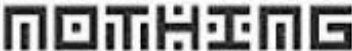

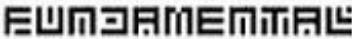

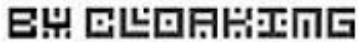
口யR5E느트 표 iTE맴ㅁㄴㅁㄷㄷㅁㄴㅡ 5 Vol 2, No. 2/2015

Asian Journal of Humanity, Art and Literatulue 


\section{Impact of Psychological Well-Being on the Vocabulary Acquisition Level of Nigerian Adolescents Learning French Language in Rural Settings}

\section{Adejumo Gbadebo Olubunmi ${ }^{1}$, Maryam Tar ${ }^{2}$}

${ }^{1}$ Department of Psychology, Covenant University, NIGERIA

${ }^{2}$ Department of Languages and General Studies, Covenant University, NIGERIA

ISSN: 2311-8636 (Print)

ISSN: 2312-2021 (Online)

Volume 2, Number 2/2015

DOI prefix: 10.18034/ajhal

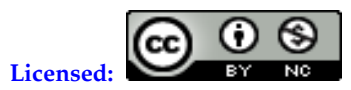

Conflict of Interest: None Declared

Email for correspondence: adejumod2001@yahoo.com
Source of Support: Nil

\section{ABSTRACT}

There is now clearer recognition that, in a country as culturally and linguistically diverse as Nigeria, specific attention must be paid to the mental readiness of learners especially in acquiring language different from their first language or lingua franca such as French language. Vocabulary acquisition is part of the psychology of foreign language learning that has received short shrift from applied linguistics, and has been very largely neglected by recent developments in research. This study therefore examined the impact of psychological well-being on the vocabulary acquisition level of Nigerian adolescents learning French language in rural settings. Survey research design was adopted in this study. Sixty eight students from fourteen secondary schools were randomly selected for this study with age range 15 to 18 years. They were made up of 38 males representing $52.9 \%$ and 30 females representing $47.1 \%$. Out of this sample $42 \%$ were in SS1, 36\% in SS2 and $22 \%$ in SS3. All these students had French language as one of subjects they were taking in school. These schools were located in rural areas in Ogun and Oyo states, Southwest Nigeria. A questionnaire was developed to measure students' psychological well being while cloze test was used to measure vocabulary acquisition level. The two instruments yielded 0.78 , and 0.76 test-retest reliability respectively with 0, 64 Cronbach Alpha for Psychological well being measure and 0.66 for cloze test. The findings revealed low level of performance in the five subscales of Psychological Well being Measure, self-acceptance, quality ties to other, autonomy in thought and action, the ability to manage complex environments to suit personal needs and values, the pursuit of meaningful goals and a sense of purpose in life and continued growth and development as a person. The study equally reported low level of vocabulary acquisition of French language across all the levels. A significant impact of psychological wellbeing on the vocabulary acquisition of French language was found at $r=0.62$, adj $\mathrm{r}^{2}=0.59$ and $\mathrm{f}(1,66)=48.26, \mathrm{p}<0.05$. It was concluded that improved psychological wellbeing will definitely leads to high level of vocabulary acquisition of French language among students even in rural areas. It was recommended that health-promoting factors for maintaining good health should be strengthened in learners for positive learning outcomes.

Key Words: psychological well-being, vocabulary acquisition, functional health 


\section{INTRODUCTION}

Students in Nigerian secondary schools are motivated to learn French language more than their predecessors. The National Policy on Education officially states that:

For smooth interaction with our neighbours, it is desirable for every Nigerian to speak French. Accordingly, French shall be the second official language in Nigeria and it shall be compulsory in Primary and Senior Secondary Schools, but nonvocational elective at the Senior Secondary School (NPE, 2004)

Today, with the world's borders more porous than ever, foreign language training needs to be an important part of any serious student's academic curriculum. In fact, some model and private schools now advertise the study of languages such as French, Chinese, Japanese, or Arabic to have an edge over their competitors. The studying of a foreign language such as French has been reported to improve skills and grades in mathematics and English Studying a foreign language can improve students' analytic and interpretive capacities. Connections are becoming inevitable among people, nations and organizations of the world which warrants a huge need for knowing more than one foreign or international language. Therefore, the use of common language remains a strong key in the areas such as trade, tourism, international relations between governments, technology, science and media (Ademola, 2010).

Obviously, words are the component structures of language; they combine to form sentences and come in eight different varieties called parts of speech. However, a person's vocabulary is the set of words within a language that are familiar to that person. A vocabulary serves as a usual and fundamental tool for communication and acquiring knowledge. Acquiring an extensive vocabulary is one of the largest challenges in learning a foreign language. This partly because word can be defined in multiple ways, depending on the context in which it is used. Learning context can also pose a lot of challenges to learning a foreign language. Learning context refers to the learning environment. It is the socio-culturo-political environment where learning takes place. The learning context can include the teachers, the peers, the classroom climate or ethos, the family support, the social, cultural tradition of learning, the curriculum, and the availability of input and output opportunities. Learning context is different from language context which refers to the textual or discoursal place in which a particular word or structure can be found. Learning contexts constrain the ways learners approach learning tasks. The most rural schools in Nigeria today have children with almost nil or no exposure to French language, teachers' language proficiency is in question and here are the parents who can not support their wards in learning the language.

Apart from the location of the students in local or rural areas, their state of psychological well-being can stand between them and success in acquiring French vocabulary. Psychological well-being indicates physical and mental wellness. Singh (1990) has stated that psychological well-being is difficult to define. It has been taken to consist of discomfort or desirability and from any disturbance of mental functions. It is a somewhat malleable concept which has to do with people's feelings about everyday life activities. Such feelings may range from negative mental states or psychological strains such as anxiety, depression, frustration, emotional exhaustion, unhappiness, dissatisfaction to a state which has been identified as positive mental health (Jahoda, 1958; Warr, 1978). This study, therefore, investigated the impact of psychological well-being on the vocabulary acquisition level of Nigerian adolescents learning French language in rural settings 


\section{Statement of the Problem}

There is now clearer recognition that, in a country as culturally and linguistically diverse as Nigeria, specific attention must be paid to the mental readiness of learners especially in acquiring language different from their first language or lingua franca such as French language. Vocabulary acquisition is part of the psychology of foreign language learning that has received short shrift from applied linguistics, and has been very largely neglected by recent developments in research.

Rode et al. (2005) claimed that broader contextual and attitu-dinal variables might influence student's achievement which includes vocabulary acquisition. Scholars, including psychologists, have conducted many research studies to identify the factors associated with academic performance, among which religious orientation ( $R O)$, psychological well-being (PWB), and self-esteem (SE) have been found recognizably important (Chamorro-Premuzic \& Furn-ham, 2005; Smetana, Campione-Barr, \& Metzger, 2006; Steinberg \& Morris, 2005). The psychological well-being of students has also been reported to be critical to their academic success. Those students with higher psychological wellbeing typically receive higher grades and are unlikely to experience academic failure (Andrews \& Wilding, 2004; Daugherty \& Lane, 1999; DeBerard, Speilmans, \& Julka, 2004).

\section{METHODS}

\section{Design}

This study adopted a survey design. However, questionnaire and cloze test were adopted to collect.

\section{Sample}

Sixty eight students from fourteen secondary schools were randomly selected for this study with age range 15 to 18 years. They were made up of 38 males representing $52.9 \%$ and 30 females representing $47.1 \%$. Out of this sample $42 \%$ were in SS1, 36\% in SS2 and $22 \%$ in SS3. All these students had French language as one of subjects they were taking in school. These schools were located in rural areas in Ogun and Oyo states, Southwest Nigeria.

\section{Instrument}

A questionnaire was developed to measure students' psychological well being while cloze test was used to measure vocabulary acquisition level. The two instruments yielded 0.78, and 0.76 test-retest reliability respectively with 0, 64 Cronbach Alpha for Psychological well being measure and 0.66 for cloze test.

Hypothesis 1: There is no significant difference in the level of Psychological Well-being of students across levels.

Table 1 Analysis of Variance of difference in the level of Psychological Well-being of students across levels

\begin{tabular}{|l|l|l|l|l|l|}
\hline $\begin{array}{l}\text { Source of } \\
\text { Variance }\end{array}$ & $\begin{array}{l}\text { Sum of } \\
\text { Squares }\end{array}$ & $\begin{array}{l}\text { Degrees of } \\
\text { Freedom }\end{array}$ & $\begin{array}{l}\text { Mean } \\
\text { Square }\end{array}$ & F & Sig \\
\hline Between & 836.84 & 2 & 418.42 & 1.37 & \multirow{2}{*}{$0.71^{* *}$} \\
\cline { 1 - 3 } Within & 19901.7 & 65 & 306.18 & & \\
\hline Total & 20738.54 & 67 & & & \\
\hline
\end{tabular}

**Not Significant 
The findings revealed low level of performance in the five subscales of Psychological Well being Measure, self-acceptance, quality ties to other, autonomy in thought and action, the ability to manage complex environments to suit personal needs and values, the pursuit of meaningful goals and a sense of purpose in life and continued growth and development as a person. The finding equally revealed no significant difference in the level of Psychological Well-being of students across levels at $\mathrm{f}_{(3,68)}=1.37$.

Hypothesis 2 There is no significant impact of psychological wellbeing on the vocabulary acquisition of French language

Table

\begin{tabular}{|c|c|c|c|c|c|}
\hline \multicolumn{6}{|c|}{$\begin{array}{l}\mathbf{R}=0.62, \\
\text { Adj } \mathbf{r}^{2}=0.59, \\
\text { Std. Error of the Estimate }=1.594\end{array}$} \\
\hline $\begin{array}{l}\text { Source of } \\
\text { Variance }\end{array}$ & $\begin{array}{l}\text { Sum of } \\
\text { Squares }\end{array}$ & $\begin{array}{l}\text { Degrees of } \\
\text { Freedom }\end{array}$ & $\begin{array}{l}\text { Mean } \\
\text { Square }\end{array}$ & $\mathbf{F}$ & Sig \\
\hline Regression & 416.91814 & 1 & 416.91814 & 48.26 & .000 \\
\hline Residual & 570.174 & 66 & 8.639 & & \\
\hline Total & 987.0921 & 67 & & & \\
\hline
\end{tabular}

The study revealed a significant impact of psychological wellbeing on the vocabulary acquisition of French language at $r=0.62$, adj $\mathrm{r}^{2}=0.59$ and $\mathrm{f}_{(1,66)}=48.26, \mathrm{p}<0.05$.

\section{Discussion}

This research has revealed low level of psychological well-being and reported no significant difference in the level of psychological well-being of students across levels. The social and economic environment is found to be a primary cause of mental health problems. Psychological models of mental health, quintessentially, emphasize the key role of a healthy, loving, supportive, connected childhood in producing well-adjusted adolescents. Socioeconomic and societal problems tend to overlap with educational problems. The standard of living in many rural communities is low and some of the problems affect their school.

The majority of youngsters in rural communities are exposed to a lot of maladies at a tender age, and this causes multiple obstacles in their attempt to acquire education. Young girls, because they do not see a point of attending school - let alone to learn - think becoming pregnant at young age is a way of life. For teenage boys, they consume drugs and alcohol. Learners are expected to overcome many educational and socio-economics challenges - often without support - in order to learn. It does not take an enquiring mind to see that there are bad conditions at many rural public schools.

Sadly enough the research finding indicated a significant impact of psychological wellbeing on the vocabulary acquisition of French language Earlier findings indicated that adolescents coming from an economically disadvantaged environment appeared to have less motivation and lowered expectations for themselves compared to peers living in better circumstances (Greenberg, Weissberg, O’Brien, Zins, et al., 2003; Zins, Weissberg, Wang, \& Walberg, 2004).

In conclusion, psychological wellbeing impact positively on vocabulary acquisition of French language among students in rural areas. Poor mental health is associated with social exclusion, unhealthy lifestyle, risks of violence and physical ill-health. These conditions are inimical to positive outcomes in all academic endeavors. 


\section{RECOMMENDATION}

There should be emphasis on and investment in preventative and health promotion work, with particular attention to adolescent mental health and the links between mental health services and education services in rural areas. The recovery approach, the well-being agenda and psychological perspectives all strongly support prevention work - particularly 'secondary prevention'.

\section{REFERENCES}

Andrews, B., \& Wilding, J. M. (2004). The relation of depression and anxiety to life-stress and achievement in students British Journal of Psychology, 95, 509-521.

Chamorro-Premuzic, T., \& Furnham, A. (2005). Personality and intellectual competence. Mahwah, NJ: Lawrence-Erlbaum Associates.

Daugherty, T. K., \& Lane, E. J. (1999). A longitudinal study of academic and social predictors of college attrition. Social Behavior and Personality, 27, 355-362.

DeBerard, M. S., Speilmans, G. I., \& Julka, D. C. (2004). Predictors of academic achievement and retention among college freshman: A longitudinal study. College Student Journal, 38, 66-80.

Federal Republic of Nigeria. (2004). National Policy on Education. Lagos: NERDC Press

Jahoda, M. (1958). Current concepts of positive mental health. New York: Basic Books

Rode, J. C., Arthaud-Day, M. L., Mooney, C. H., Near, J. P., Baldwin, T. T., Bommer, W. H., \& Rubin, R. S. (2005). Life satisfaction and student performance. Academy of Management Learning \& Education, 4, 421-433

Singh, D. (1990. Concept of psychological well-being: Western and Indian perspectives. NIMHANS Journal, Vol.8, PP.1-11

Steinberg, L., \& Morris, A. S. (2001). Adolescent development. Annual Review of Psychology, 52, 83-110.

Warr, P.B. (1978). A study of psychosocial wellbeing, British Journal of Psychology, 69,111-121.

This article is is licensed under a Creative Commons AttributionNonCommercial 4.0 International License. Attribution-NonCommercial (CC BYNC) license lets others remix, tweak, and build upon work non-commercially, and although the new works must also acknowledge \& be non-commercial.

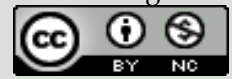

How to Cite: Olubunmi AG and Tar M. 2015. Impact of Psychological WellBeing on the Vocabulary Acquisition Level of Nigerian Adolescents Learning French Language in Rural Settings Asian Journal of Humanity, Art and Literature, 2, 87-92. 


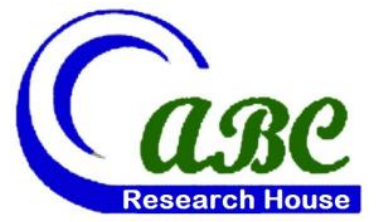

- Off Pantai Dalam, Kuala Lampur, Malaysia

- Road \# 4, Shyamoli, Dhaka-1207, Bangladesh

3900 Woodhue Place, Alexandria, VA 22309, USA

http://journals.abc.us.org/ / www.abcjournals.net

Asian Business Consortium (ABC) is a multi-disciplinary research, training, publishing, digital library supporting and service house. Though founded in 2010 as the Business and Computing organization of Asia, it was reconstituted as the ABC in 2011. It has been working for creating and nurturing talents in USA, Malaysia and Bangladesh since its inception. The objectives of consortium are solely centered round the welfare and humane attitude of the founders who enthusiastically took up this noble cause and materialized it with a view to promote research and educational activities for the encouragement of scholars to develop their knowledge, to publish their analysis oriented scientific researches in international Journals, books, the task of organizing workshops, seminars, conferences, training, personality development programs and allied services.

In addition to research activities, $\mathrm{ABC}$ provides a good number of scholarships to the poor and meritorious students at various levels of education throughout the world. It plays an important role in the field of research by funding research projects and publishing the research papers. This consortium will unquestionably become the mouth-piece of the dark horses and unacknowledged scholar whose endowed and commendable contributions shall be provided an outlet keeping in mind the greater good of the larger society of the world.

$A B C$ runs the following international referred journals for creating a platform to share the thoughts of professionals, scholars and academicians throughout the world.

\section{ABC Publications (ABC Journals)}

- Asian Accounting and Auditing Advancement (4A Journal)

- Asian Business Review (ABR)

- Asian Journal of Applied Sciences and Engineering (AJASE)

- Global Disclosure of Economics and Business (GDEB)

- $\mathrm{ABC}$ Journal of Advanced Research (ABC-JAR)

- International Journal of Reciprocal Symmetry and Theoretical Physics (IJRSTP)

- American Journal of Trade and Policy (AJTP)

- Asian Journal of Humanity, Art and Literature (AJHAL)

- Malaysian Journal of Medical and Biological Research (MJMBR)

- Asia Pacific Journal of Energy and Environment (APJEE)

- $\quad$ Engineering International (EI)

- $\quad$ ABC Research Alert (Online)

Each journal home page provides specific information for potential authors and subscribers. Open access policy, the quick review process, rich editorial boards and quality publications have already made $A B C$ Journals unique. ABC Journals are published under the direct supervisions of renowned academicians of the world.

Collaboration in Conference: $\mathrm{ABC}$ considers high-quality conference papers for publication. Please contact us for detailed information.

Collaboration in Publishing: If you like to start writing a book, propose a new journal or advertise in $A B C$ journals, please feel free to contact us. 